RIGHTS AND OBLIGATIONS IN

NORTH-SOUTH RELATIONS 


\title{
Rights and Obligations in North-South Relations
}

Ethical Dimensions of Global Problems

\author{
Edited by \\ Moorhead Wright
}

Palgrave Macmillan 
ISBN 978-1-349-07776-2 ISBN 978-1-349-07774-8 (eBook)

DOI 10.1007/978-1-349-07774-8

(C) Moorhead Wright, 1986

Softcover reprint of the hardcover 1st edition 1986

All rights reserved. For information, write:

Scholarly \& Reference Division,

St. Martin's Press, Inc., 175 Fifth Avenue, New York, NY 10010

First published in the United States of America in 1986

ISBN 978-0-312-68234-7

Library of Congress Cataloging-in-Publication Data

Main entry under title:

Rights and obligations in north-south relations.

Bibliography: $p$.

Includes index.

1. Developing countries-Foreign relations-Moral and ethical aspects. 2. Developing countries-Foreign economic relations-Moral and ethical aspects.

3. International economic relations-Moral and ethical aspects. I. Wright, Moorhead. II. Title. $\begin{array}{llll}\text { JX1391.R53 } 1985 & 172^{\prime} 4 & 85-22212\end{array}$

ISBN 978-0-312-68234-7 


\section{Contents}

Notes on the Contributors vii

Preface ix

$\begin{array}{ll}\text { Introduction } & 1\end{array}$

1 Human Rights and the Diversity of Morals: A Philosophical Analysis of Rights and Obligations in the Global System

A. J. M. Milne

2 Europe and the World: The Imperial Record V. G. Kiernan

3 Economics and Ethics in the Development of Natural Resources

A. I. MacBean

4 The Ethics of Foreign Aid

$H$. W. Singer

5 International Sanctions: Ethical and Practical Perspectives Margaret Doxey

6 Non-intervention: Ethical 'Rules of Disregard' and ThirdWorld Conflicts

S. C. Nolutshungu

7 Confrontation or Community? The Evolving Institutional Framework of North-South Relations

Jane Davis

Index 


\section{Notes on the Contributors}

Jane Davis is a Lecturer in International Politics at the University College of Wales, Aberystwyth. She contributes a chapter on defence organizations and developments to The Annual Register and is writing a general survey of third-world conflicts, which together with international organization is her main teaching field.

Margaret Doxey is Professor of Political Studies at Trent University, Peterborough, Ontario, Canada. Her Economic Sanctions and International Enforcement, now in its second edition, is widely regarded as the standard work in the field.

V. G. Kiernan is Emeritus Professor of Modern History at the University of Edinburgh. His books include Lords of Human Kind, European Empires from Conquest to Collapse and Marxism and Imperialism.

A. I. MacBean is Professor of Economics at the University of Lancaster. He has been an economic adviser in the Ministry of Overseas Development, a member of the Harvard Economic Advisory Service in Pakistan, and a consultant for a variety of organizations. His publications include Export Instability and Economic Development and (as co-author) Meeting the Third World Challenge.

A. J. M. Milne is Professor of Politics at the University of Durham. $\mathrm{He}$ is the author of The Social Philosophy of English Idealism, Freedom and Rights and The Right to Dissent: Issues in Political Philosophy.

S. C. Nolutshungu is a Lecturer in Government at the University of Manchester. Among his publications are Changing South Africa and South Africa. 
H. W. Singer is Emeritus Professor at the Institute of Development Studies, University of Sussex. He spent twenty-two years with the United Nations and has had wide experience as a consultant for such organizations as FAO, UNIDO, UNCTAD and UNICEF. His many publications include Rich and Poor Countries, The Strategy of International Development and Technologies for Basic Needs.

Moorhead Wright, editor, is a Senior Lecturer in International Politics at the University College of Wales, Aberystwyth, specializing in the ethical and philosophical problems of the subject. He has edited Theory and Practice of the Balance of Power, 1486-1914 and co-edited American Thinking about Peace and War. 


\section{Preface}

The global situation has been characterized in recent years by an ever-widening gap between rich and poor countries with a corresponding growth in awareness of the need for a North-South dialogue. The failure of this dialogue to produce many concrete achievements has been due both to the complexity of the problems involved and the tendency for both sides to seek short-term political advantages. Demands by the developing countries for a New International Economic Order, for example, have met with little sympathy among the industrialized nations, who see their traditional superiority threatened.

These developments have prompted a considerable amount of scholarly literature on the ethical dimension of relations between developed and developing countries, but there has been no attempt to provide an overall survey of the moral problems presented by a wide variety of issues. This is the aim of the essays in this book which have been written by experts on their chosen topics and reflect a wide range of viewpoints. The opening chapters provide the philosophical and historical background necessary to an understanding of the various ethical positions and arguments. Subsequent chapters tackle specific issues in current North-South relations and the institutional framework which has arisen to deal with them.

Early drafts of six of the chapters were presented at an interdisciplinary conference sponsored by the Department of International Politics, University College of Wales, at the University of Wales Conference Centre, Gregynog Hall, near Newtown, Powys, 2-4 July 1984. The editor wishes to thank the British Academy for a travel grant which enabled Margaret Doxey to deliver her paper, the Advisory Board which administers the endowment associated with the Department's Woodrow Wilson Chair for financial support for the conference, Jane Davis and James Piscatori for their helpful suggestions at the planning stage, the warden and staff of Gregynog Hall for helping to make the conference such a pleasant occasion, and the other participants for 
their lively and well-informed involvement in the discussions. In this last category special thanks are due to the late Professor Hedley Bull, who stepped in at the last minute to introduce and comment upon one of the papers with his usual acumen and wide-ranging knowledge. We dedicate the book to the memory of this outstanding scholar, respected colleague and good friend.

M.W. 